Original Research

\title{
The Use of Sulfur Waste to Protect Against Corrosion of Metal Implants
}

Mariusz KSIĄŻEK*

Building Research Institute Wroclaw-Warsaw (The Instytut Techniczny Budownictwa WrocławWarszawa), ul. Trawowa 25, lok. 8, 54-614 Wrocław, Poland; E-Mail: ksiazekmariusz@wp.pl

* Correspondence: Mariusz KSIĄŻEK; E-Mail: ksiazekmariusz@wp.pl

Academic Editor: Hossein Hosseinkhani

Special Issue: Applications and Development of Biomaterials in Medicine

Recent Progress in Materials

2021, volume 3, issue 2

doi:10.21926/rpm.2102023
Received: March 24, 2021

Accepted: May 20, 2021

Published: June 15, 2021

\begin{abstract}
Metal parts of endoprosthesis have a detrimental effect on the bones that come into contact with them and on the entire body of the patient. Coating them with biocompatible layers (hydroxyapatite and bioglass) has not yet brought about permanent results. In this study, the author showed the possibility of using a binder containing sulfur waste for this purpose. The sulfur binder is used industrially in electrical engineering and construction applications. The chemical properties of elemental sulfur indicate that it is a biocompatible material. Previous studies on rats have shown that sulfur binder is a biocompatible material. A steel surgical nail covered with sulfur waste, placed in a sheep's femur, showed excellent stabilization by adhering bone tissue to the composite layer. From the results, it is convinced that the composite made of sulfur waste creates new possibilities in the field of production of biocomposites for surgical applications. The prepared biocomposite composition was sulfur waste-69.5\%, mineral quartz dust-30\%, and technical soot- $0.5 \%$. There is no information on similar studies in the world literature. So far, sulfur waste has been used in the electrical and construction industries. The literature shows that no researcher has used sulfur waste in biocomposites. So, the current study is a pioneering experimental study in this area.
\end{abstract}

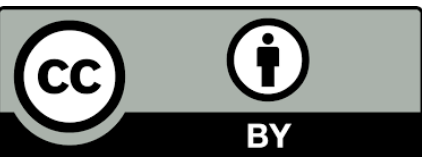

(c) 2021 by the author. This is an open access article distributed under the conditions of the Creative Commons by Attribution License, which permits unrestricted use, distribution, and reproduction in any medium or format, provided the original work is correctly cited. 


\section{Keywords}

Biomaterial; biocomposite; biocoating; polymerized sulfur; sulfur waste; sulfur composite

\section{Introduction}

Several tons of sulfur wastes are deposited in landfills, which develops the problem related to their management. One of the fruitful ways of reusing sulfur waste is a biocomposite formation. Accordingly, the prepared biocomposites as a surface protection agent for metal endoprosthesis were carried out in the Building Research Institute Wroclaw-Warsaw (The Instytut Techniczny Budownictwa Wrocław-Warszawa). The experimental steps involved in the preparation of binder was the optimization of synthesis conditions to achieve the proper composition of biocomposite, characterization of the biocomposite, selection and investigation of physical, chemical, and mechanical properties of biocomposites, investigations related to their tangent and original adhesion capability to a metal endoprosthesis, and its biocompatibility. Presently, polymer sulfur composite has several industrial applications [1-4]. For example, in construction, it is used as surface protection against corrosion of building elements $[1-3,5,6]$. An interesting and novel application of the sulfur polymer composite can be the formation of the biocompatible protective coating of the metal endoprosthesis. Corrosion of metal endoprosthesis is a major problem in implantology because it shortens their service life $[3,5,7,8]$. Chemical and electrochemical corrosion in the aggressive medium of a living organism practically concerns all-metal implants, not only metal endoprosthesis [2, 9-12]. The main approach to prevent corrosion is surface protection of the metal implant, which significantly extends its failure-free life [13-15].

In this context, a preliminary study was conducted to show the efficacy of polymer sulfur composite as a tight protective biocompatible surface protection layer for the metal endoprosthesis. For this purpose, sulfur binder and additives collected from industrial waste were used as source material [16-18], and it is composed of sulfur and carbon black $[2,11,19,20]$.

The special features of polymer sulfur composite are resistance toward aggressive aqueous solutions, high surface hydrophobicity (i.e., low water absorption), and relatively high adhesion to many surfaces, including metal surfaces [21, 22, 31]. Polymer sulfur composite is a highperformance thermoplastic material that is prepared by the thermal treatment $\left(150-160{ }^{\circ} \mathrm{C}\right)$ of sulfur waste and additives $[2,6,23-25,31]$. The suitable physicochemical properties of the polymer sulfur composites, such as chemical passivity, excellent resistance toward acids and salt solutions, and hydrophobic properties [17, 18, 26, 31], find their application as a biocompatible surface coating material.

The main component of the sulfur polymer composite is an industrial waste, which is deposited on high heaps and landfills [2, 27-29, 31] (Figure 1). 


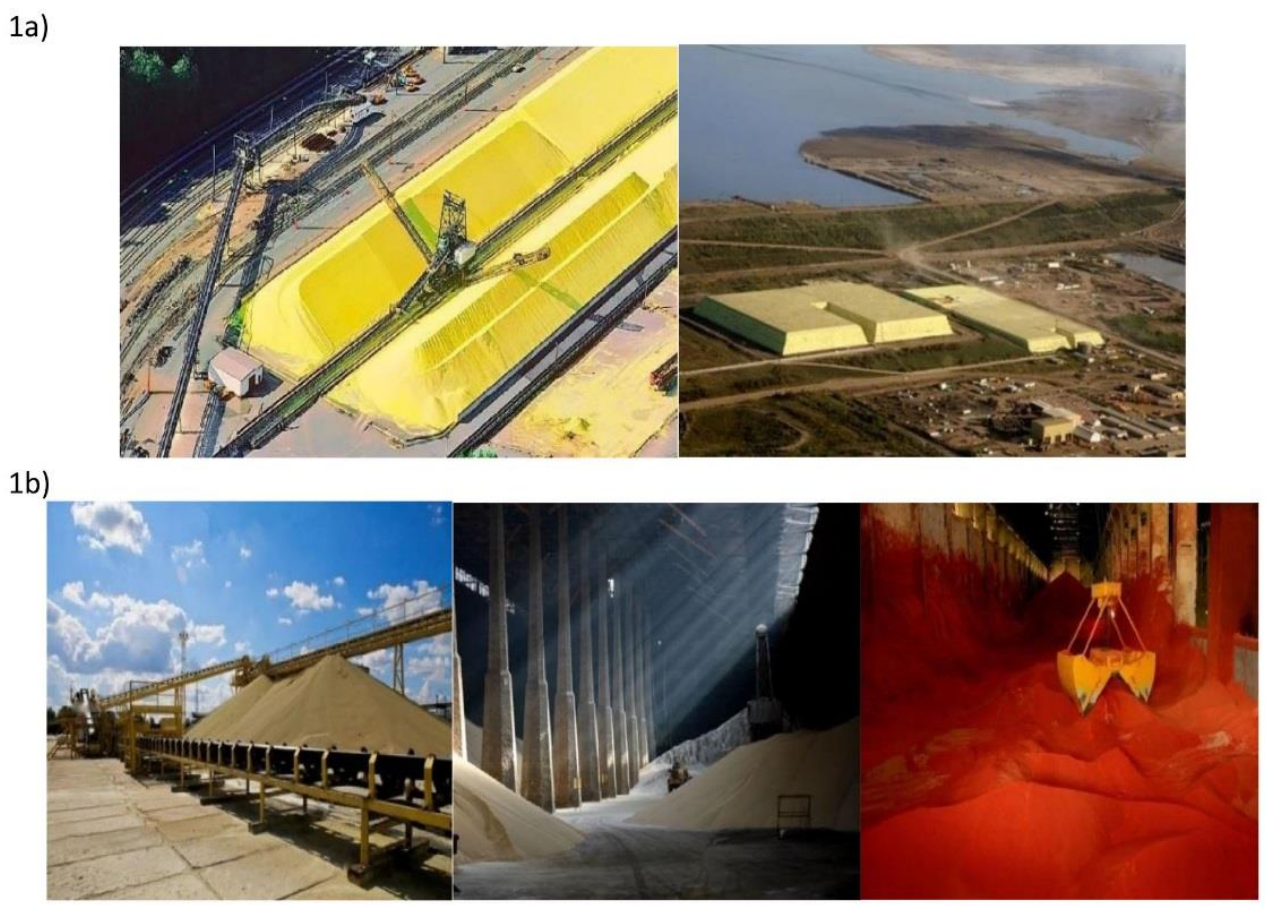

Figure 1 View of industrial sulfur waste in landfills 1a) in Europe, 1b) in Poland [2, 28].

The properties of the elemental sulfur atoms have been well reported in the literature. Accordingly, at ambient temperature, the polymerized sulfur present in the industrial waste as binders exists in the rhombic crystalline form ( $\alpha-S)$, it melts at $110^{\circ} \mathrm{C}$ and forms monocyclic crystals $(\beta-S)$, which changes again to the $\alpha-S$ at $95.6^{\circ} \mathrm{C}[2,3,10,12,17,18,29-31]$.

The temperature-dependent polymerization of sulfur as follows [2, 3, 12, 19, 30-32]:

$>160^{\circ} \mathrm{C}$ it is brown and featured with high viscosity,

between 200 and $250^{\circ} \mathrm{C}$ it is in dark brown with relatively high viscosity,

$>250^{\circ} \mathrm{C}$ depolymerizations and viscosity reduction start at $400^{\circ} \mathrm{C}$. At this stage, sulfur is very fluid and finally, it reaches a boiling temperature at $444.6^{\circ} \mathrm{C}$. Therefore, the rapid cooling of boiling sulfur in water changes its form from fluid to an elastic-plastic state with a brown-yellow colored product. In this state, sulfur is composed of two different polymerized forms: $S_{\lambda}$ (yellow) and $S_{\mu}$ (dark redbrown). $S_{\mu}$ has a higher molecular mass than $S_{\lambda}$. $S_{\mu}$ was obtained by treating colloidal state $[2,6,30-$ 33] sulfur after boiling with water and $\mathrm{Ca}(\mathrm{OH})_{2}$ and further precipitation with $\mathrm{HCl}$. Later, hydrolysis with alcohol yielded $S_{\lambda}[30-34]$.

From the point of chemical reactivity, the modified form of sulfur was in its oxidized form and it can be easily reduced into other sulfides and organo-sulfur compounds. It is noteworthy to point out that direct application of elementary sulfur is rare. Commonly it is used to prepare cement for special purposes, e.g., to join ceramic and metallic parts of electric insulators. The mechanical properties of this cement are good (strength about $40 \mathrm{MPa}$ by compression), and its chemical inertness is also appreciated (in comparison to the Portland cement containing concretes). Other than this, sulfur is also used in dermatology [3, 30-35].

The idea of the sulfur application in orthopedic implants was based on the following observations $[3,23,31]$ : metal implants manifest their harmful influence on the surrounding bone and other functions, e.g., metabolic, immunological, neoplastic of the patient. Also, covering the metal implant surface with biocompatible layers made up of either hydroxyapatite or bioglass did not 
provide satisfactory results. Remarkably, after few years, the coated layers were absorbed by the biochemical action or split away from the metal surface. Sometimes, the preparation of the metal surface prior to deposition of a layer decreases the implant mechanical strength. On the other hand, the sulfur-metal bond and the sulfur-ceramic bond are very stable in industrial applications. So the oxidizing influence of the physiological medium on sulfur might be negligible by considering the hydrophobic character and the formed different sulfur compounds (e.g., sulfites, sulfates) are well tolerated by this medium [30-36].

The sulfur polymer composite prepared from the industrial waste can be applied in the industries objects $[2,8,12,17,28,31]$ : in sealing reinforced concrete constructions against corrosion; in sealing of concrete and reinforced concrete structures resistant to harsh environments such as seawater, wastewater, and chemicals (e.g., tanks containing chemicals and drinking water or concrete flooring); in sealing the inner surface of the prefabricated elements (e.g., a pipe, a sludge well or a cesspool) of the sewage system in order to obtain chemical resistance and smooth surface; in proofing reinforced concrete piles against the sea-water action; in the protection of asbestos cement slabs, used in building external walls, against the release of asbestos microfiber [30].

Therefore, to verify the possibility of the sulfur application in the metal implants, experiments were carried out. The biological reaction during the contact between sulfur and living tissue was explored in experimental animal models [31].

\section{Experimental Procedure}

\subsection{Biomaterials}

The initial biomaterials used in the technological procedure for special sulfur biomaterial production were: sulfur binder applied as industrial waste (Figure 1, [2, 3, 28-31]), quartz, and technical soot. Sulfur cement was used in experiments that contained sulfur waste (69.5\%), quartz $(30 \%)$, and technical soot (0.5\%). The grain size of quartz was under $0.2 \mathrm{~mm}$. Also, sulfur binder and technical soot are applied as industrial waste.

\subsubsection{Sulfur Waste}

Initially, the elementary sulfur waste was used as a binder in the production of special sulfur biomaterial. However, in spite of excellent mechanical properties after preparation, the samples exhibited low stability, so spalling and failure occurred after a short period [17]. The development of modified sulfur binder contributed to better endurance of sulfur biomaterial, which led to its use in implantology [27, 31].

Sulfur waste, the basic component for a modified sulfur binder, originates from technical soot. Both the elementary and the prepared modified sulfur were investigated by scanning electron microscope (SEM) (JEOL JSM-5800) with EDX (Figure 2), and their microstructures were analyzed according to the literature $[2,3,7,29,37]$. The results showed that the elementary sulfur waste was composed of dense orthorhombic crystals of the alpha form $\left(S_{\alpha}\right)$, Figure 2a, while modified sulfur consists of plate monoclinic crystals of the beta form $\left(S_{\beta}\right)$, partially polymerized in zigzag chains, Figure $2 b$. From these results, it was proved that modification of sulfur was achieved [17]. 
2a)
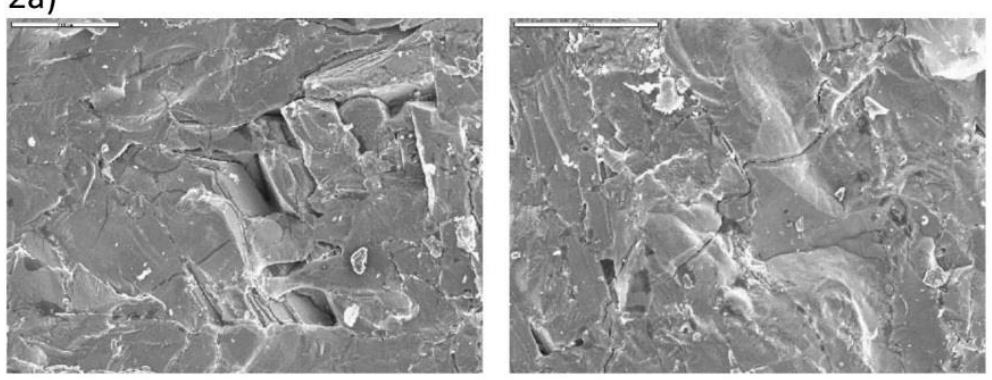

2b)

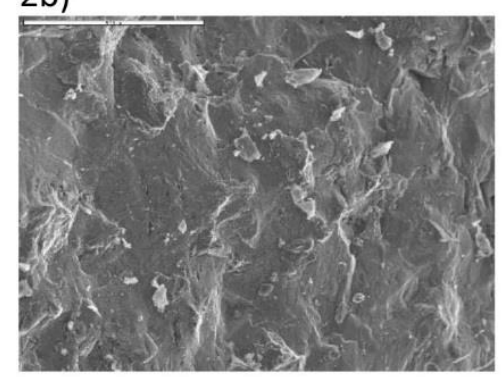

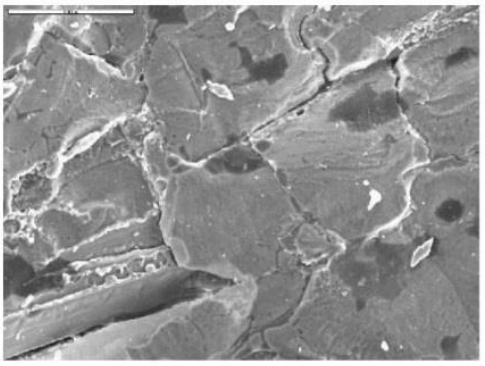
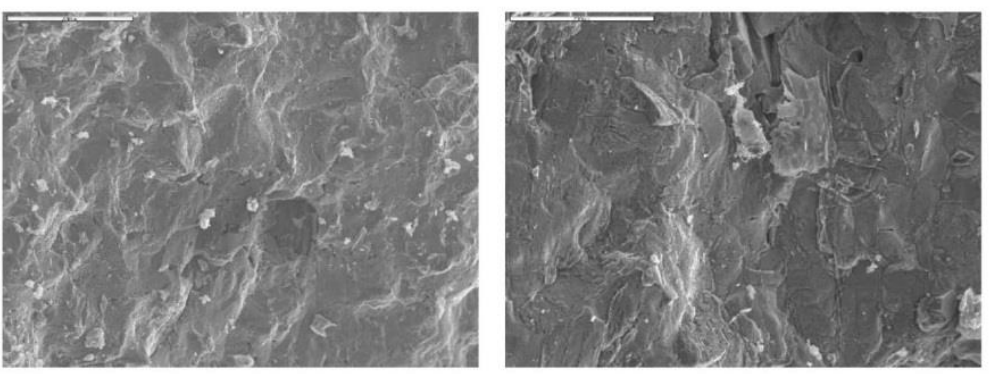

Figure 2 Structure of sulfur: 2a) elementary, 2b) modified [3, 23, 38].

According to the results presented in Table 1, the composition of the sulfur binder applied as the industrial waste consisted of $97.86 \% \mathrm{~S}_{8}$ fine sulfur, $2.13 \%$ oil, $0.01 \%$ ash, and producer "Siarkopol" Tarnobrzeg. The results of the preliminary tests were analyzed, and the polymerized sulfur in the industries objects possessed the best properties among the tested composites, and it was selected for further studies. The information about the preparation of the polymerized sulfur composition and experimentally determined properties are presented in Tables 2, 3, and 4, respectively. The sulfur binder used for these investigations is shown in Figure $3[1-3,6]$.

Table 1 Composition of the sulfur binder used as industrial waste $[1-3,6]$.

\begin{tabular}{lll}
\hline & Component & Content [\%] \\
\hline 1 & Fine sulfur, $\mathrm{S}_{8}$ & $\mathbf{9 7 . 8 6}$ \\
2 & Oil & $\mathbf{2 . 1 3}$ \\
3 & Ash & $\mathbf{0 . 0 1}$ \\
4 & Leaven as $\mathrm{H}_{2} \mathrm{SO}_{4}$ & $\mathbf{0 . 0 0 1}$ \\
5 & Piece volatile & $\mathbf{0 . 0 2}$ \\
6 & Remainder on the sieve $0,063 \mathrm{~mm}$ & $\mathbf{0 . 0 1}$ \\
\hline
\end{tabular}

Table 2 Preparation of polymerized sulfur.

\begin{tabular}{llll}
\hline & $\begin{array}{l}\text { Temperature } \\
\text { the } \\
\text { polymerization } \\
{\left[{ }^{\circ} \mathrm{C}\right]}\end{array}$ & $\begin{array}{l}\text { Time of } \\
\text { polymerization } \\
{[\mathrm{min}]}\end{array}$ & $\begin{array}{l}\text { Time } \\
\text { coagulation [min] }\end{array}$ \\
\hline $\begin{array}{l}\text { Sulfur applied as industrial } \\
\text { waste }\end{array}$ & $\mathbf{1 5 0 - 1 6 0}$ & $30-60$ & $30-40$ \\
\hline
\end{tabular}


Table 3 Composition of the polymer sulfur composite used as a biomaterial.

\begin{tabular}{|c|c|c|}
\hline \multicolumn{3}{|c|}{ Content in [\%] of total composite mass } \\
\hline Binder & Filler & Additive \\
\hline $\begin{array}{l}\text { Sulfur } \\
\text { [\%] }\end{array}$ & $\begin{array}{l}\text { Mineral quartz dust } \\
\text { [\%] }\end{array}$ & $\begin{array}{l}\text { Technical soot } \\
{[\%]}\end{array}$ \\
\hline 69.5 & 30.0 & 0.5 \\
\hline
\end{tabular}

Table 4 Experimentally determined properties of the polymer sulfur composite used as a biomaterial.

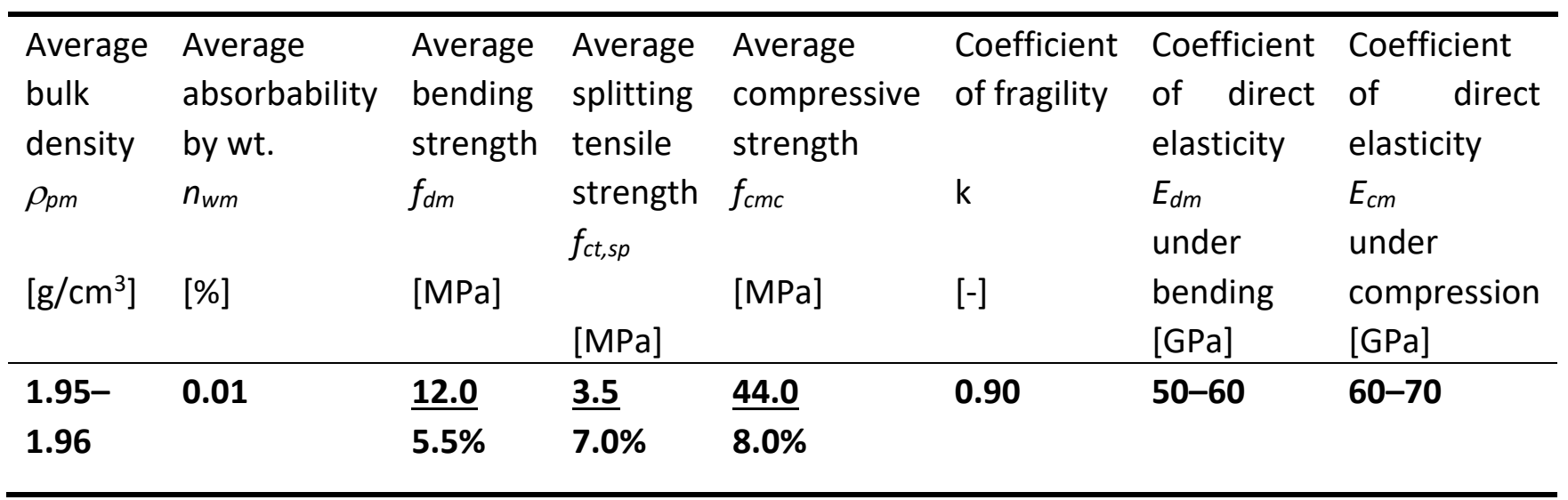

Note: The percentages under the line are coefficients of variation. 

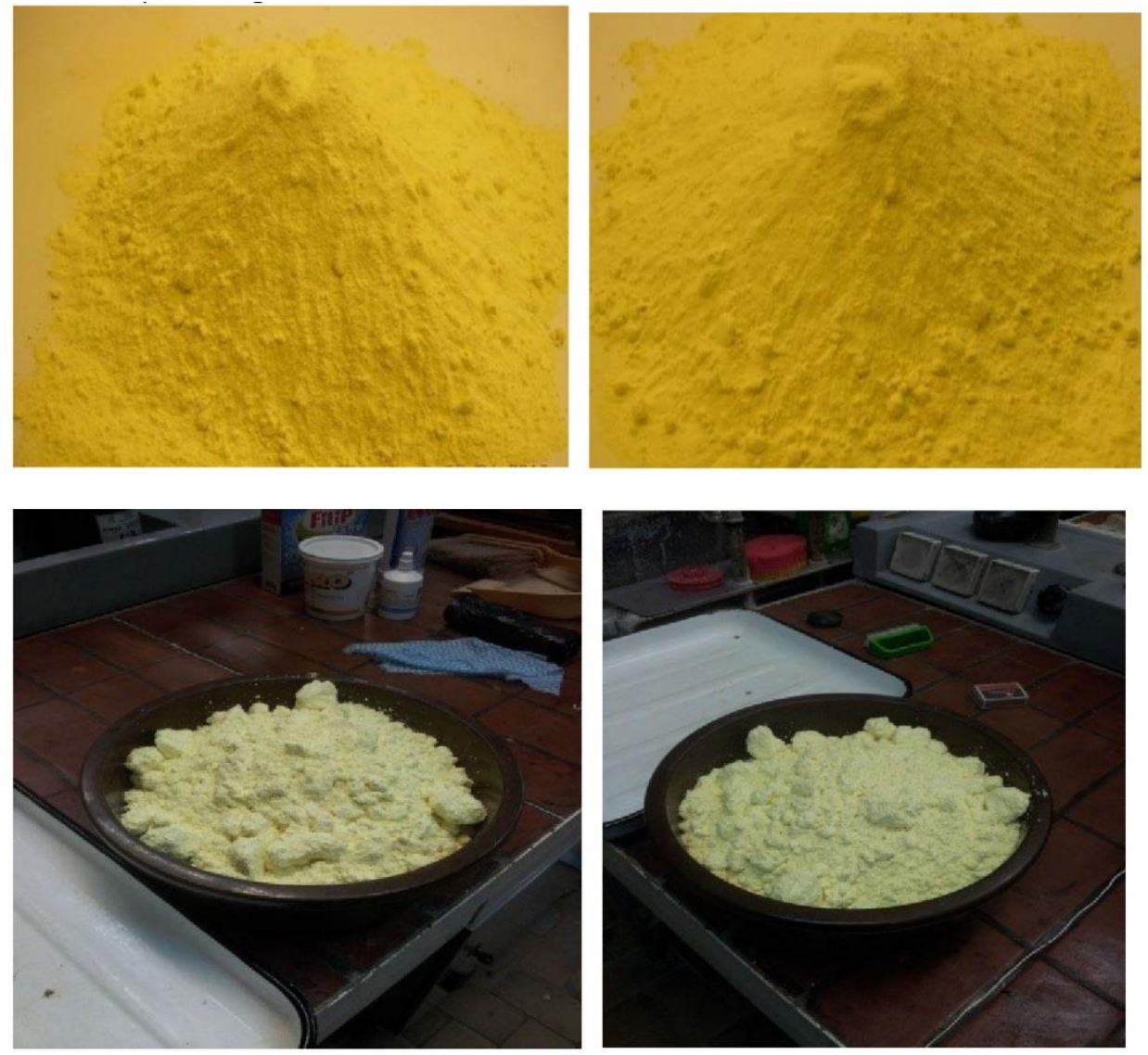

Figure $3 \mathrm{~A}$ view of the sulfur used in investigations $[2,3,8-12]$.

The viscosity of the melt of polymerized sulfur was examined. The viscosity of polymerized sulfur as a function of temperature is shown in Figure 4 [2, 3, 33-37].

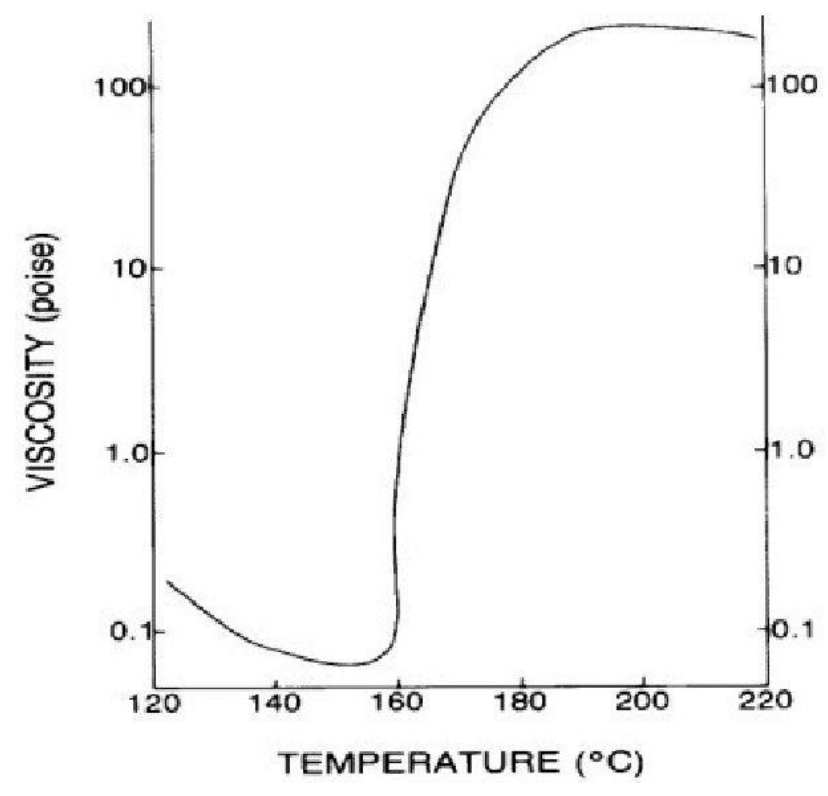

Figure 4 View of the viscosity of polymerized sulfur as a function of temperature $[2,3$, 33-37]. 


\subsubsection{Filler Waste}

The filler waste used in this production was technical soot "Seva Carb" (granulation: 0.300 $\mu \mathrm{m} .-0.330 \mu \mathrm{m}$.). Chemical analysis indicated that the filler waste mainly consisted of carbon (99.99\%).

\subsection{Preparation and Characterization of Biomaterials Samples.}

Polymer sulfur biocomposite was prepared according to the manufacturing technological procedure described in the literature $[2,3,12,20,29,30]$. The method of producing a polymer sulfur biocomposite is shown in Figure 5 [30-40]. Details of the preparation and application of the sulfur composite on the surface of the samples can be found elsewhere $[1-3,6,40]$.

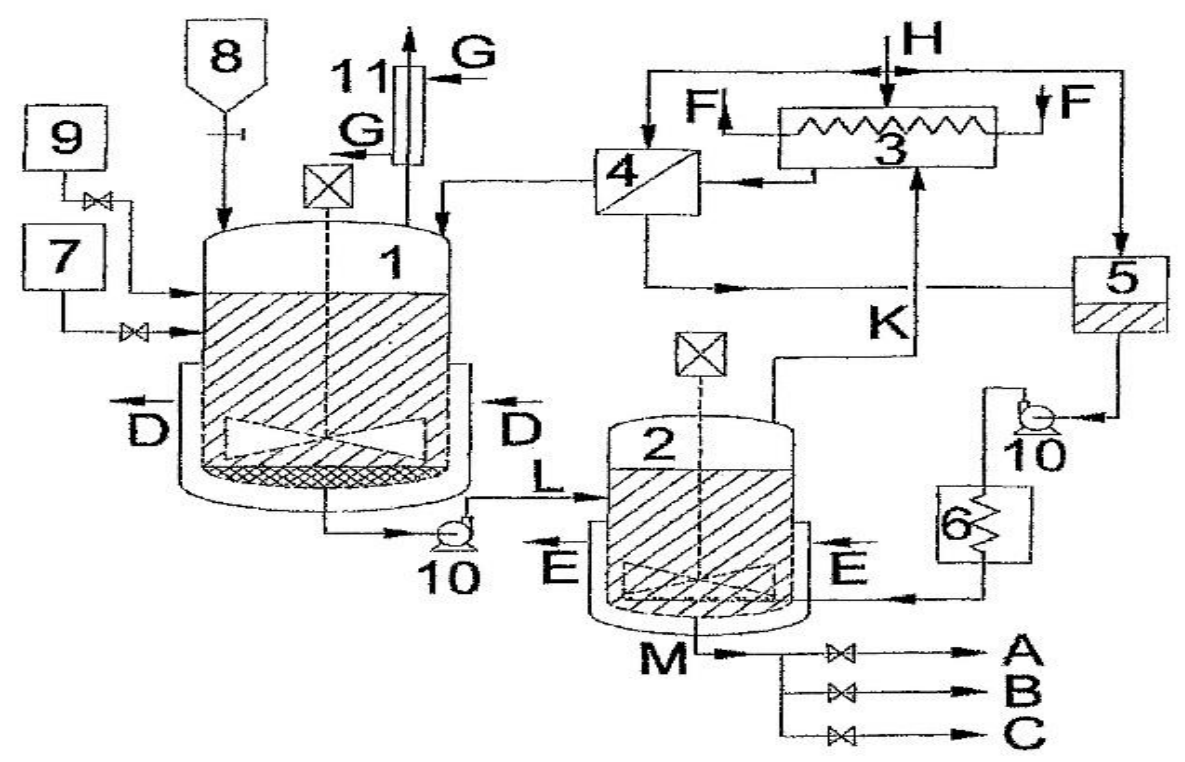

Figure 5 Scheme of production of a polymer sulfur biocomposite. Description: 1-mixer, 2-evaporator, 3-water cooler, 4-separator, 5-water tank, 6-steam generator, 7-modifier feeder, 8-sulfur feeder, 9-solvent feeder, 10-pump, 11-reflux condenser: A-for the production of sulfur concrete, B-for the production of road binders, C-for the production of biocomposites, DD-fuel oil inlet and outlet, EE-fuel oil inlet and outlet, FF-water inlet and outlet, GG-inlet and outlet water outlet, H-nitrogen $2.5 \mathrm{~atm}$, K-solvent, modifier and water vapors, L-contaminated polymer sulfur composite (for construction applications), $\mathrm{M}, \mathrm{C}$-Chemically pure polymer sulfur composite [30-40].

Chemically pure sulfur polymer composite was used as a biocomposite. First experiments were carried out on rats (Wistar breed, body mass 320-350 g). The sulfur cement was powdered manually in a ceramic mortar. The obtained diameter of the grains was under $60 \mu \mathrm{m}$. They were injected subcutaneously. Their contact with tissue was examined microscopically after 30, 90, and 180 days. The paraffin-embedded specimens were stained with hematoxylin and eosin. Their microphotographs are presented in Figures 6-14 [31]. 


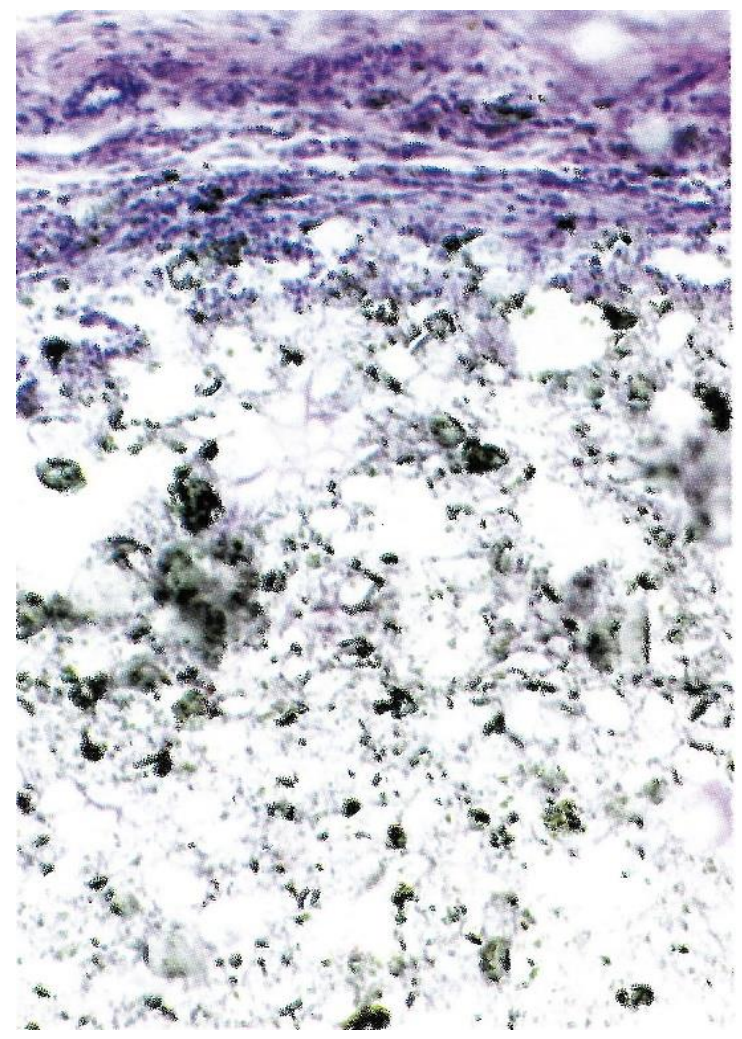

Figure 6 Histological preparations of sulfur cement grains 30 days after their implantation subcutaneously in the soft tissue of a rat [31].

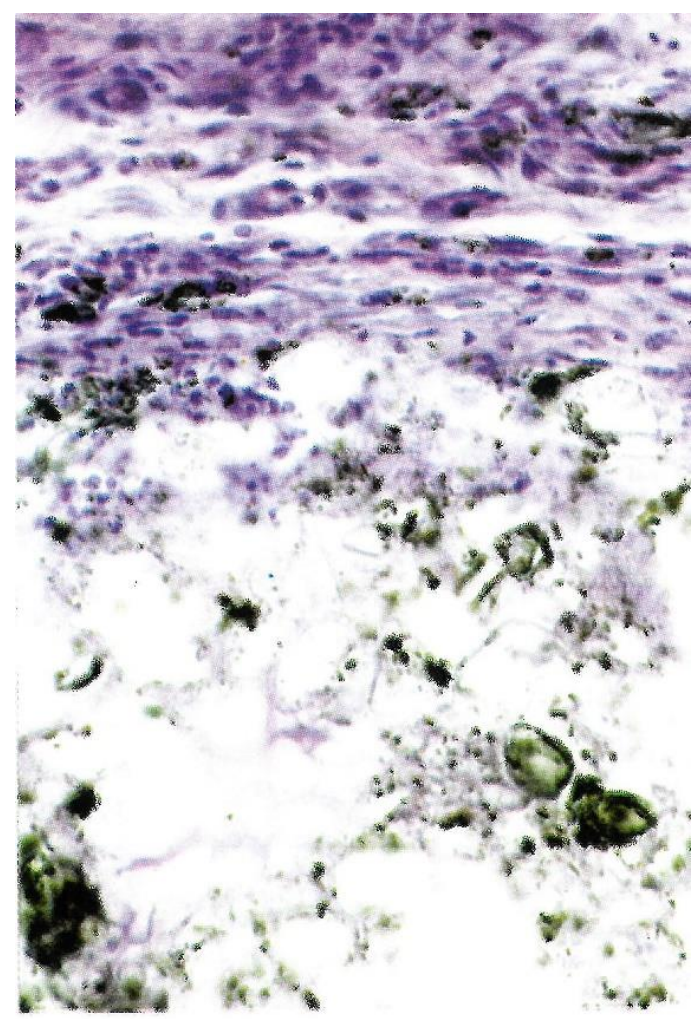

Figure 7 Histological preparations of sulfur cement grains after 30 days of their implantation subcutaneously in the soft tissue of a rat at greater magnification [31]. 
Recent Progress in Materials 2021; 3(2), doi:10.21926/rpm.2102023

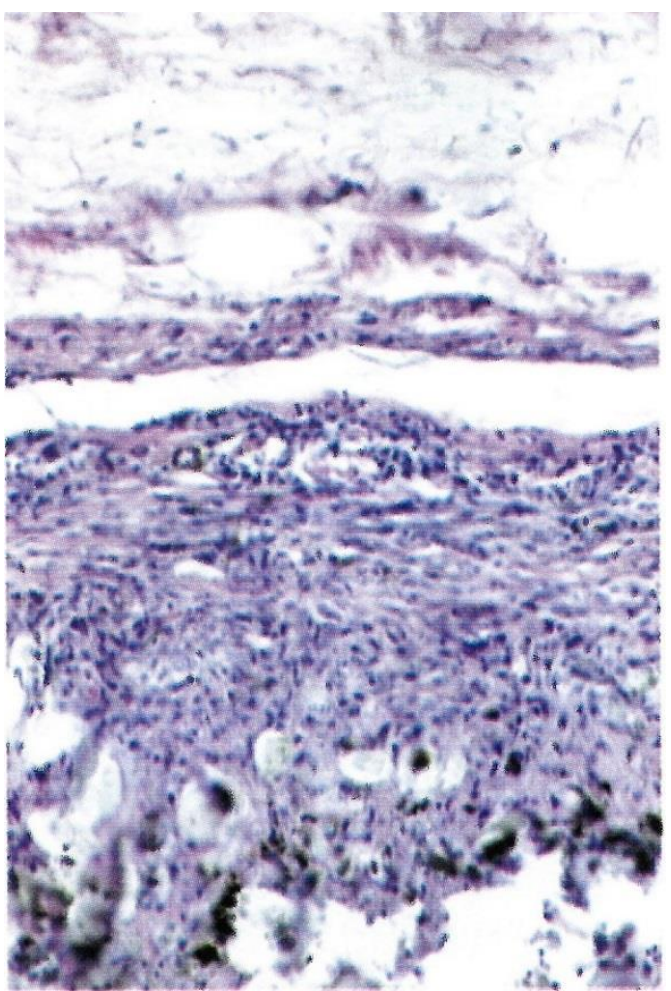

Figure 8 Histological preparation of sulfur cement grains after 90 days after implantation [31].

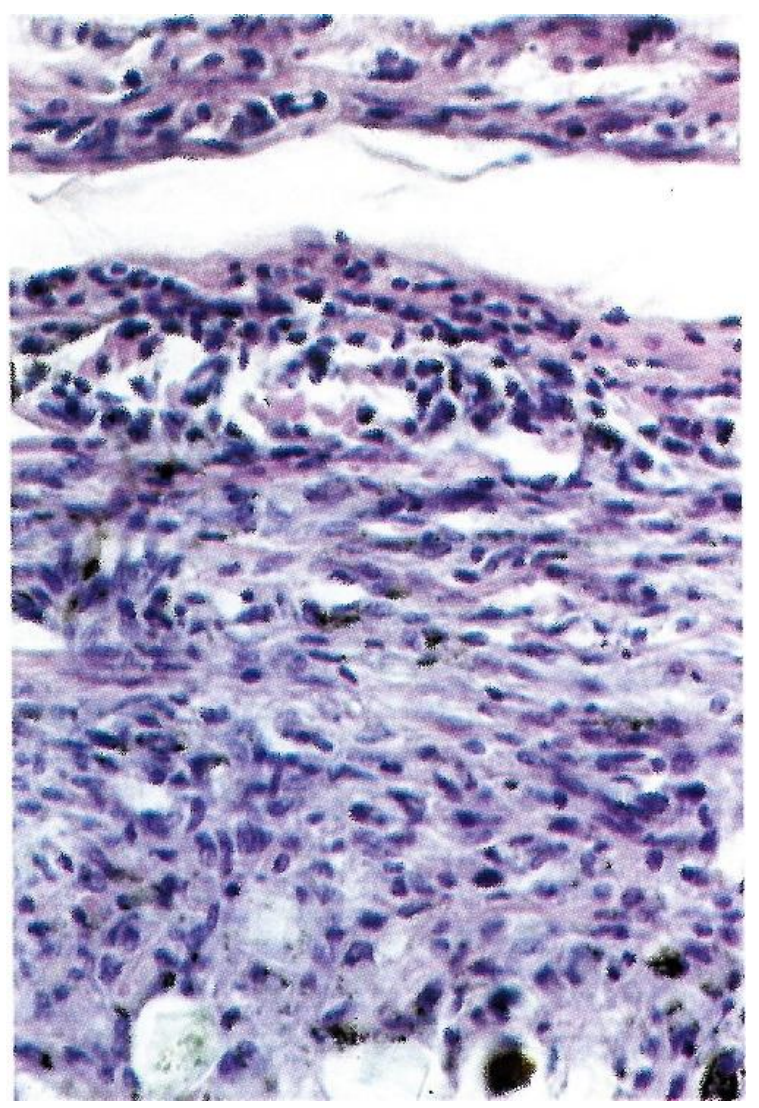

Figure 9 Histological preparation of sulfur cement grains after 90 days after implantation at greater magnification [31]. 


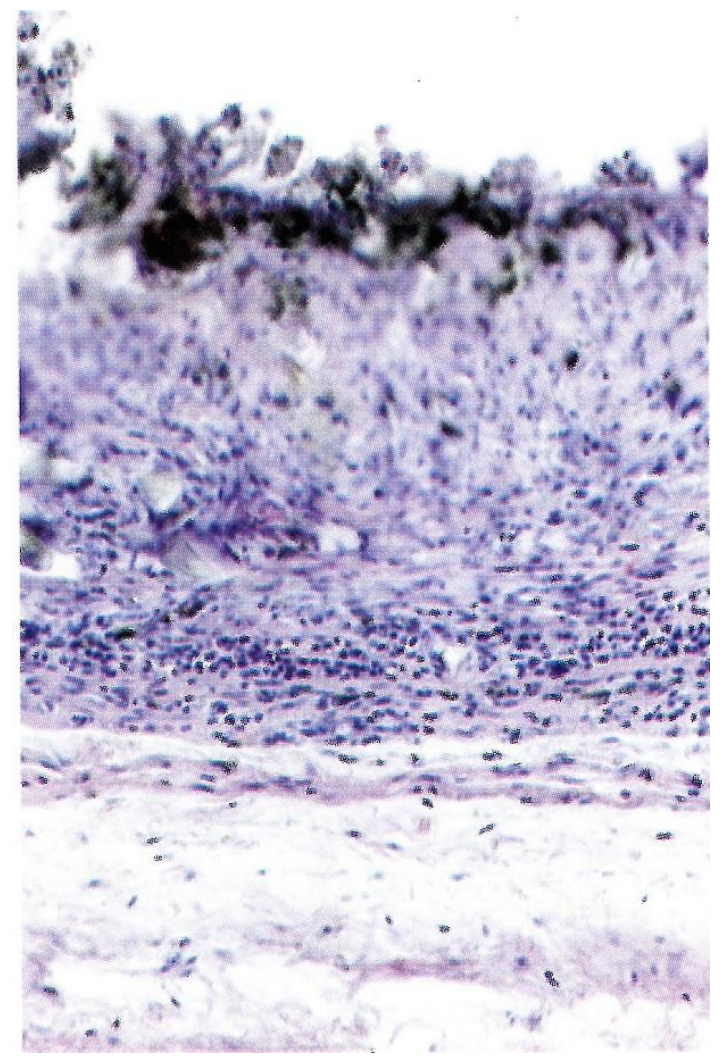

Figure 10 Histological preparation of sulfur cement grains after 180 days after implantation [31].

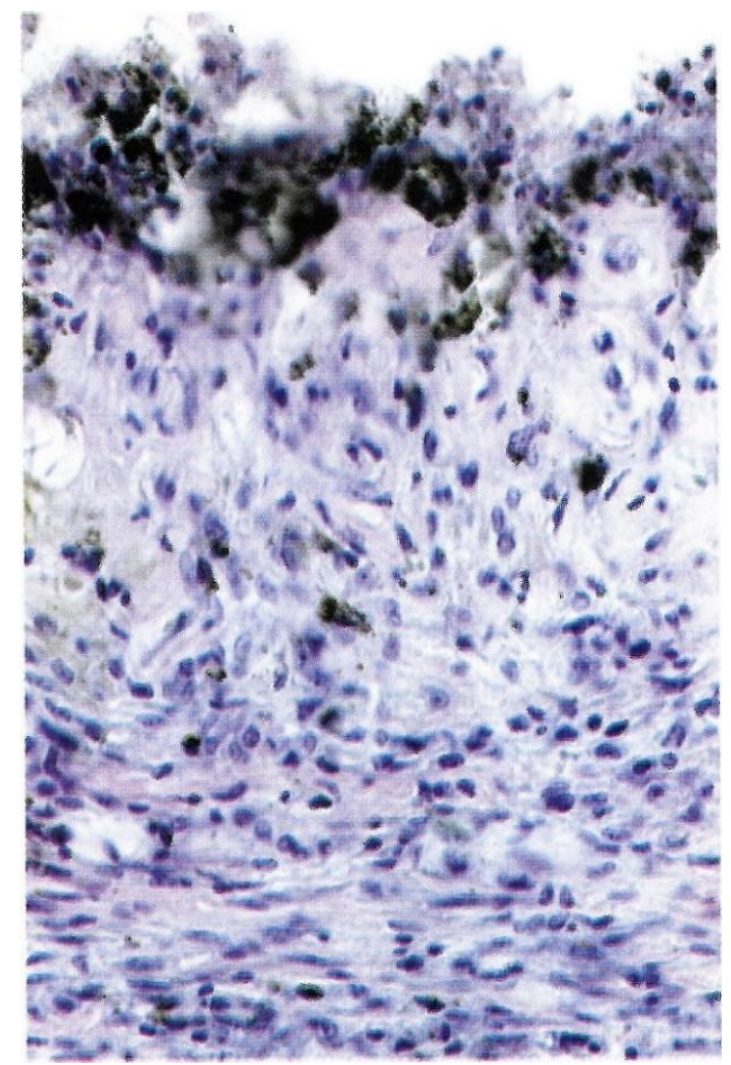

Figure 11 Histological preparation 180 days after implantation at greater magnification [31]. 


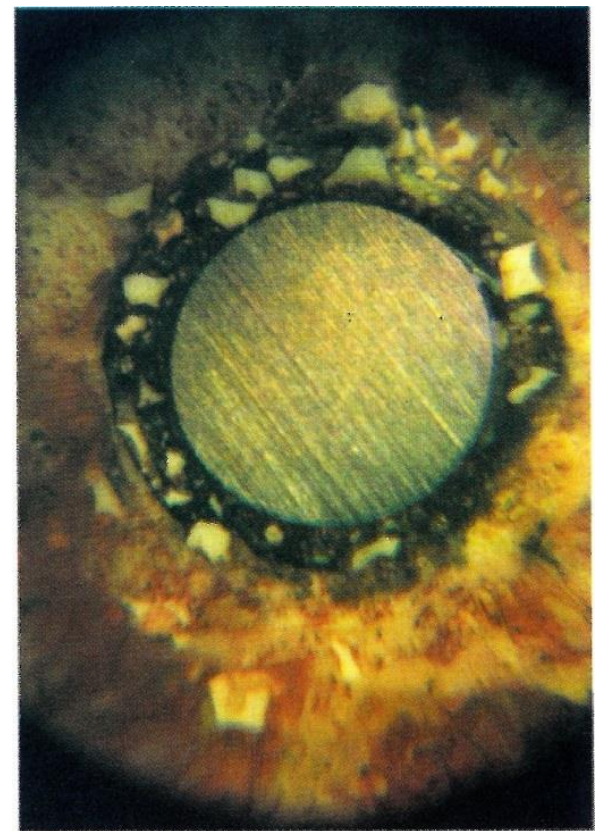

Figure 12 The steel nail was covered with sulfur cement and alumina grains nine months after implantation in the femur of a sheep. Black-sulfur cement, white-alumina grains, brown-red-mineralized tissue [31].

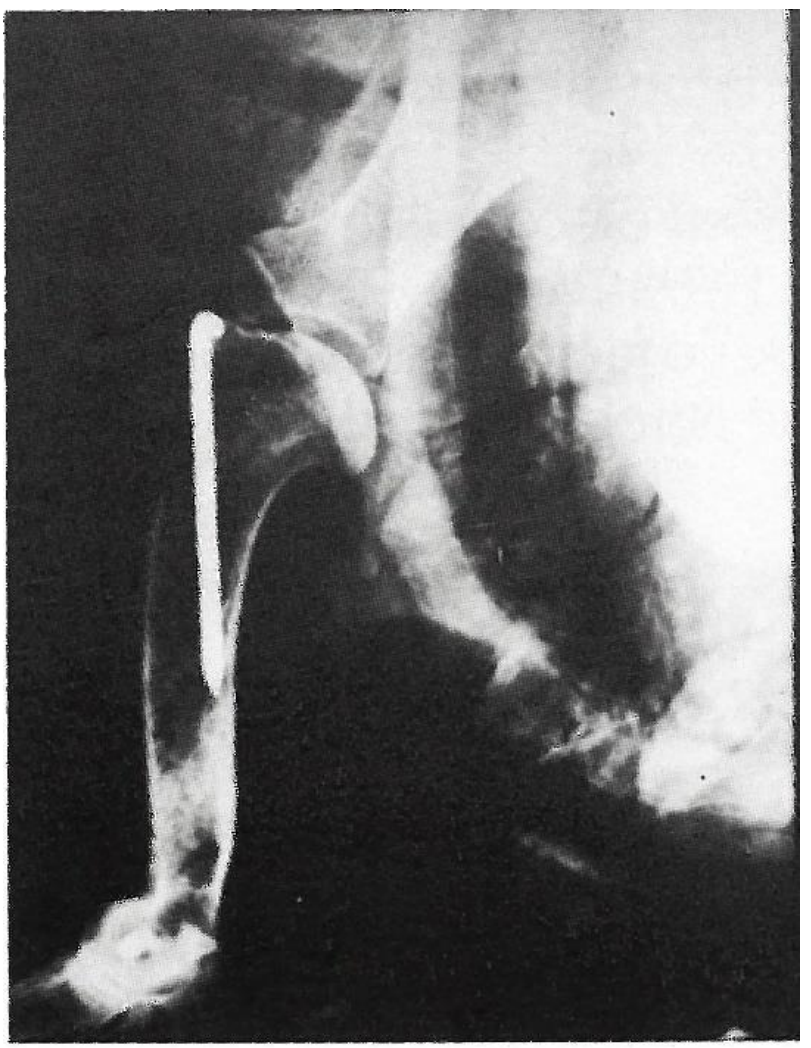

Figure 13 The radiograph of the steel nail in the femur of a sheep. There is no negative reaction in the bone tissue [31]. 


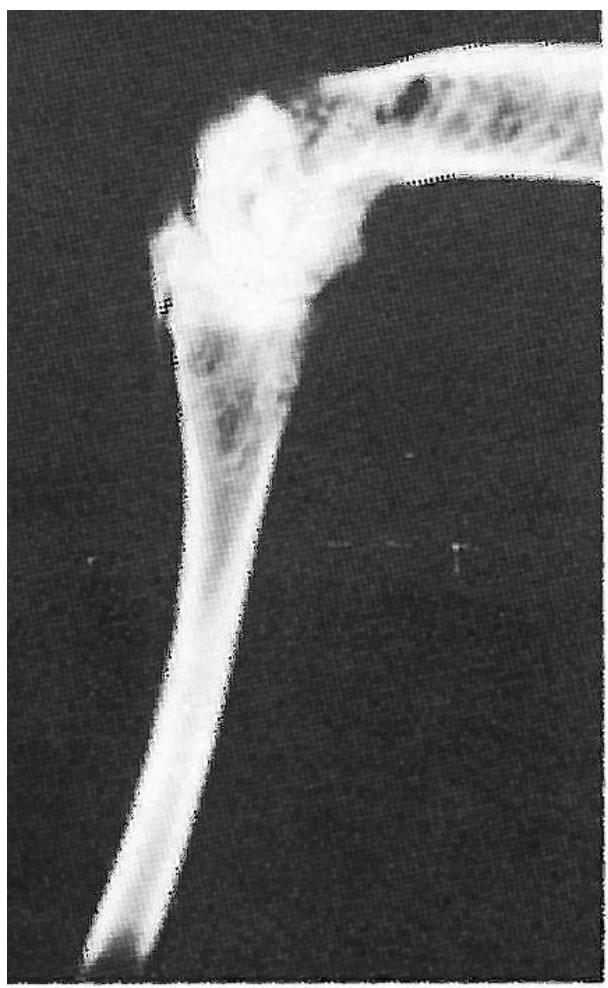

Figure 14 The radiograph of the steel nail in the femur of a sheep. There is no negative reaction in the bone tissue [31].

The sulfur cement was also introduced into the femur of a sheep. Cylinders with $4 \mathrm{~mm}$ diameter and $6 \mathrm{~mm}$ height were inserted into holes drilled in the bone. It was covered with cement and alumina grains nail was introduced into the femur of a sheep. After nine months from the date of operation, the samples for the microscopic evaluation were taken. The sections through the implant with surrounding tissue were made. They were embedded in poly(methyl methacrylate (PMMA), polished, and stained with alizarin (mineralized tissue colored in red) and methylene blue (organic substances were stained in brown-green). The microscopic observations were carried out in reflected light. The nail with the surrounding tissue is presented in Figure 12 [31].

\section{Results and Discussion}

\subsection{Experiments on Rats}

During the observation period (till 180 days), implanted animals behaved normally. They were examined post mortem for internal organs (lungs, liver, spleen, kidney), glands, skin, muscles, and bones did not demonstrate any pathological changes [31].

After 30 days from the date of implantation sulfur cement containing grains were embedded by the connective tissue capsule, which contained many collagen fibers, fibrocystic, and some fibroblasts. This capsule distinctly separated the implant from the surrounding without affecting the tissue. Implants did not result in the blood-derived inflammatory infiltration. Macrophages and histiocytes were not present (Figure 6 and Figure 7) Święcki et al. [31]. 
After 90 days of the multiplication, fibroblasts were peripherally observed around the implanted grains. Collagen fibers penetrated between these grains. The inflammatory state was not observed (Figure 8 and Figure 9) Święcki et al. [31].

After 180 days proliferation, collagen-producing fibroblasts still existed. Therefore, a thick layer of the new connective tissue was formed. No inflammatory state was noted (Figure 10 and Figure 11) Święcki et al. [31].

These experiments confirmed the possible biocompatibility of the sulfur-containing cement. Nevertheless, some inflammatory tissue factors were observed, which did not interrupt the multiplication of fibroblasts and collagen fibers [31].

\subsection{Experiments on Sheep}

The cylinders, made of sulfur cement, inserted into the sheep femur were surrounded by fibrous tissue. Their contact with bone tissue was not observed. Such biological reaction was probably caused by the hydrophobic character of the cylinder surfaces. Sulfur-containing cylinders were biologically treated as foreign bodies and separated from the femur bone tissue. On the contrary, the composite presented in Figure 12 indicated its strong fixation on bone [31]. This compositesteel nail covered with sulfur cement and additionally with alumina grains made a biological connection with bone which penetrated the alumina pores and pits. The irritation of soft tissue as observed in rats (multiplication of fibrous and collagen fibers) did not appear in this case. The differences in the biological reaction of soft tissue and bone on various implants were stated by researchers. The bioactive "Hench glass" in bone tissue involves inflammation in the soft tissue. Powdered hydroxyapatite involves inflammation in this tissue in the same manner [31].

\section{Conclusions}

It can be concluded from the preliminary test results that the tested biocomposite can provide surface corrosion protection to the metal endoprosthesis. Sulfur biocomposites have not been applied earlier for this purpose. There is no available literature on this subject.

The first biological experiments (on rats) with sulfur-containing cement confirmed the biocompatibility of elementary sulfur waste. Nevertheless, its hydrophobic character indicated the fact that some modifications of its surface are needed to make a proper connection with bone tissue. One of these possible modifications was applied in the presented experiments in the form of the surgical nail covered with sulfur cement and alumina grains. The excellent fixation of this nail in a sheep femur was observed in radiographs and histological specimens (Figure 6-Figure 14) [31]. Our results offer a reasonable basis to presume that a harmful metal-living tissue contact can be completely eliminated by this approach. These preliminary experiments confirmed the biocompatibility of the sulfur composite. Nevertheless, it contained some irritating surrounding tissue factors, which did not interrupt the multiplication of fibroblasts and collagen fibers. Perhaps, elementary sulfur waste would find many clinical applications as the component of several biomaterials [31].

The biocorrosion test results presented in this paper indicate that the special sulfur biomaterial applied as an industrial waste can provide surface protection against corrosion of metal implants [31]. 
The preliminary tests, carried out at the Building Research Institute Wroclaw-Warsaw (The Instytut Techniczny Budownictwa Wrocław-Warszawa), were quite extensive. However, we still recommend further studies to ensure its biocompatibility. Additionally, simple and fast technology of applying the biomaterial to the surface of metal implants in surgical practice needs to be developed in the future.

\section{Author Contributions}

The author did all the research work of this study.

\section{Funding}

European Union (European Commission). Scientific grant No. ITB/01/2019-2023.

\section{Competing Interests}

The author declares and assures that no conflict exists. The author declares and confirms that all the study protocols were carried out in accordance with the relevant guidelines. The author declares and confirms that he has obtained copyright permission from all authors.

\section{References}

1. Książek M. RETRACTED: Use in the building cement composites impregnated with special polymerized sulfur. J Build Eng. 2015; 4: 255-267.

2. Książek M. Resistance to chemical attack of cement composites impregnated with a special polymer sulfur composite. Corros Rev. 2016; 34: 211-229.

3. Książek M. Application of sulfur waste in biomaterials. Compos B Eng. 2021; 217: 108848.

4. Bahgat Radwan A, Abdullah AM, Mohamed A, Al-Maadeed MA. New electrospun polystyrene/Al2O3 nanocomposite superhydrophobic coatings; synthesis, characterization, and application. Coatings. 2018; 8: 65.

5. Dawood ET, Ramli M. The effect of using high strength flowable system as repair material. Compos B Eng. 2014; 57: 91-95.

6. Książek M. The analysis of thermoplastic characteristics of special polymer sulfur composite. Contin Mech Thermodyn. 2017; 29: 11-29.

7. Książek M. The experimental and innovative research on intensity of corrosion processes influenced by tensile stress for reinforcing steel covered with sulphur polymer composite applied as industrial waste material. Adv Sci Lett. 2013; 19: 247-251.

8. Ksiazek M. The influence of penetrating special polymer sulfur binder-Polymerized sulfur applied as the industrial waste material on concrete watertightness. Compos B Eng. 2014; 62: 137-142.

9. El Gamal MM, El-Dieb AS, Mohamed AM, El Sawy KM. Performance of modified sulfur concrete exposed to actual sewerage environment with variable temperature, humidity and gases. J Build Eng. 2017; 11: 1-8.

10. Książek M. The sulphur binders-their potential possibilities of using in buildings. In: Prace Naukowe Instytutu Budownictwa Politechniki Wrocławskiej. Konferencje. Wrocław: Politechnika Wrocławska; 1999. pp.77-78. 
11. Ksiażek M. Niszczenie mechaniczne kompozytów siarkowych. In: Prace Naukowe Instytutu Budownictwa Politechniki Wrocławskiej. Konferencje. Wrocław: Politechnika Wrocławska; 2001. pp.105-112.

12. Książek M. The experimental research on properties, structures and applies polymer sulfur composites as the industrial waste material in the industry objects. Mater Struct. 2015; 48: 3269-3278.

13. EL AZZAOUI EL, ElAouni N, Bakhta A, Harfi AE. Elaboration of new epoxy resin octafonctionnelle by chemical modification of the DGEBA. Study of the rheologic parameter. Mor J Chem. 2015; 3: 338-345.

14. Gupta V, Ghosh S, Phapale V. Polymerization of elemental sulfur with various divinyl and diallyl monomers and properties of the copolymers. Phosphorus Sulfur Silicon Relat Elem. 2018; 193: 752-758.

15. Birjandi AK, Akhyani F, Sheikh R, Sana SS. Evaluation and selecting the contractor in bidding with incomplete information using MCGDM method. Soft Comput. 2019; 23: 10569-10585.

16. Gwon S, Ahn E, Shin M. Self-healing of modified sulfur composites with calcium sulfoaluminate cement and superabsorbent polymer. Compos B Eng. 2019; 162: 469-483.

17. Vlahović MM, Savić MM, Martinović SP, Boljanac TÐ, Volkov-Husović TD. Use of image analysis for durability testing of sulfur concrete and Portland cement concrete. Mater Des. 2012; 34: 346-354.

18. Vlahović M, Martinović S. The synthesis of a sulfur-polymer matrix composite and morphological analysis of the samples in extreme conditions [Internet]. Hauppauge: Nova Science Publishers; 2018. Available from: http://cer.ihtm.bg.ac.rs/handle/123456789/2417.

19. Książek M. Evaluation of acid corrosion resistance of Portland cement composites impregnated with polymer sulfur composite. Anti Corros Method M. 2017; 64: 273-285.

20. Śladowski G, Radziszewska-Zielina E, Kania E. Analysis of self-organising networks of communication between the participants of a housing complex construction project. Arch Civ Eng. 2019; 65: 181-195.

21. Jlassi K, Radwan AB, Sadasivuni KK, Mrlik M, Abdullah AM, Chehimi MM, et al. Anti-corrosive and oil sensitive coatings based on epoxy/polyaniline/magnetite-clay composites through diazonium interfacial chemistry. Sci Rep. 2018; 8: 13369.

22. Jo Y, Do J. Pull-out bond strength and flexural load test of concrete beam with ethylene-vinyl acetate-modified cement slurry-coated rebar. Adv Struct Eng. 2018; 21: 2130-2142.

23. Książek M. Experimental research of the intensity of corrosion processes influence by tensile stress for reinforcing steel covered with polymer sulphur composites. Concr Solut. 2011; 8: 257.

24. Mathews ER, Wood JL, Phillips D, Billington N, Barnett D, Franks AE. Town-scale microbial sewer community and $\mathrm{H} 2 \mathrm{~S}$ emissions response to common chemical and biological dosing treatments. J Environ Sci. 2020; 87: 133-148.

25. Vickers NJ. Animal communication: When i'm calling you, will you answer too? Curr Biol. 2017; 27: R713-R715.

26. Mozhdehi AM, Bamoharram FF, Morsali A, Sharifi AH, Sharifi S, Ganjali A. Comprehension of the role of created hydrogen bonds and adsorption energy in polyamide-nanosilica-Keggin hybrid/water on enhancement of concrete compressive strength: DFT calculations and experimental investigations. J Mol Liq. 2020; 297: 111912. 
27. Thomas C, Cimentada A, Rico J, Setién J. Sulphur content of recycled aggregates applied in concrete production. In: New Trends in Eco-efficient and Recycled Concrete. Sawston: Woodhead Publishing; 2019. pp.499-508.

28. Książek M. The research on thermoplastic properties cement composites impregnated with the waste of sulfur. Acta Mech. 2017; 228: 31-48.

29. Książek M. Protection against corrosion of reinforcing steel and concrete using polymer-sulfur composites. Proc Inst Civ Eng Constr Mater. 2017; 170: 281-296.

30. Wagenfeld JG, Al-Ali K, Almheiri S, Slavens AF, Calvet N. Sustainable applications utilizing sulfur, a by-product from oil and gas industry: A state-of-the-art review. Waste Manage. 2019; 95: 7889.

31. Święcki Z, Polesiński Z, Badura R, Osiński B, Kotz J, Buczek A, et al. Sulphur containing biomaterials. Szkło i Ceramika. 1998; 49: 32-34.

32. Yang $C, \operatorname{Lv} X$, Tian X, Wang $Y$, Komarneni S. An investigation on the use of electrolytic manganese residue as filler in sulfur concrete. Constr Build Mater. 2014; 73: 305-310.

33. Yusuf MM, Radwan AB, Shakoor RA, Awais M, Abdullah AM, Montemor MF, et al. Synthesis and characterisation of Ni-B/Ni-P-CeO2 duplex composite coatings. J Appl Electrochem. 2018; 48: 391-404.

34. Książek M. The experimental research on special polymerized sulfur composite-impregnated concrete and cement mortar. J Mater Sci Eng. 2015; 4: 2.

35. Zhou $Y$, Zheng $Y$, Pan J, Sui L, Xing $F$, Sun $H$, et al. Experimental investigations on corrosion resistance of innovative steel-FRP composite bars using X-ray microcomputed tomography. Compos B Eng. 2019; 161: 272-284.

36. Książek M. The experimental and innovative research on usability of sulphur polymer composite for corrosion protection of reinforcing steel and concrete. Compos B Eng. 2011; 42: 1084-1096.

37. Liu XB, Liu HQ, Liu YF, He XM, Sun CF, Wang MD, et al. Effects of temperature and normal load on tribological behavior of nickel-based high temperature self-lubricating wear-resistant composite coating. Compos B Eng. 2013; 53: 347-354.

38. Książek M. City sewer collectors biocorrosion. Cent Eur J Eng. 2014; 4: 398-407.

39. Książek M. Experimental research on the surface protection of concrete by polymer sulfur composite. Mag Concr Res. 2012; 64: 945-955.

40. Mysłowski W, Janiczek A. Patent. Sposób wytwarzania polimeru siarkowego i zastosowanie polimeru siarkowego. Polska; PL 211111, 2011. 


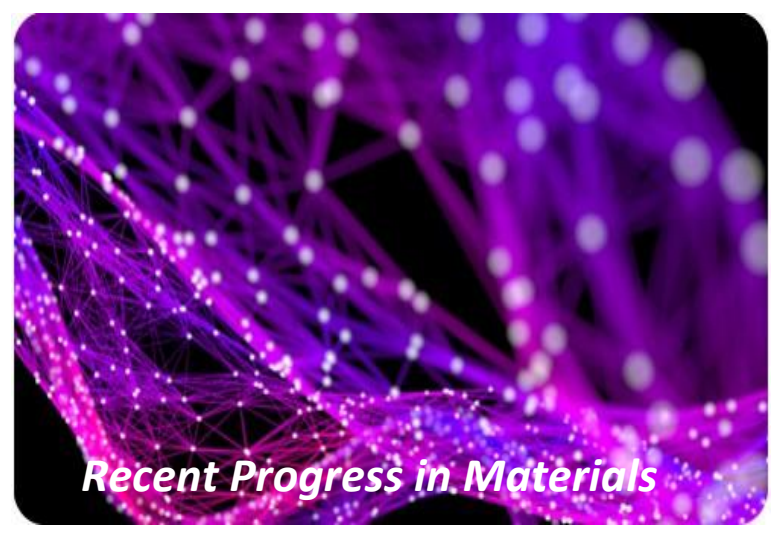

Enjoy Recent Progress in Materials by:

1. Submitting a manuscript

2. Joining in volunteer reviewer bank

3. Joining Editorial Board

4. Guest editing a special issue

For more details, please visit:

http://www.lidsen.com/journals/rpm 